\title{
Shodhana (Processing) of Gunja (Abrus precatorius Linn.) Seeds with Godugdha (Cow's milk); a pharmaceutical analysis
}

\section{Research article}

\author{
Sudipta Roy ${ }^{1}$, Rabinarayan Acharya ${ }^{2 *}$, Shukla V J \\ 1. M. Pharm scholar, 2. Associate Professor, Dept. of Dravyaguna, \\ 3. Head, Pharmaceutical Laboratory, \\ Institute for Post Graduate Teaching and Research in Ayurveda, Gujarat Ayurved University, \\ Jamnagar, India.
}

\begin{abstract}
Seeds of Abrus precatorius Linn. (Fabaceae), a poisonous plant drug, is being used in different Ayurvedic therapeutics, after proper processing (Shodhana) with some specific media. In Ayurvedic literature, media like Godugdha (cow's milk), kanji (sour gruel) nimbu swarasa (Lemon juice) etc. has been reported for processing of Gunja seeds. In the present study, the Gunja seeds were processed by using Godugdha (cow's milk) and water as media and the raw seeds were taken as control. This study reveals certain changes in different physico-chemical parameters and $\mathrm{R}_{\mathrm{f}}$ values in HPTLC of Godugdha shodhita Gunja seed in comparison to the water Shodhita and Raw Gunja seed. It is observed that the colour of the media was changed to reddish ting after each shodhana. Changes in every physico chemical parameters confirm the effect of shodhana on Gunja seed. In HPTLC analysis, varieties of Rf value were detected in raw and shodhita samples indicating change in the nature of the shodhita drugs.
\end{abstract}

Key words: Gunja, Abrus precatorius Linn, purification, shodhana, Abrin

\section{Introduction:}

Gunja (Abrus precatorius Linn.), a well-known plant of Ayurveda under Upavisha group (sub/semi poisonous group) (1), is being used extensively in different formulations with great therapeutic significance and is being advocated to use, in various diseases like Indralupta (alopecia), Shotha (edema), Krimi (helminthes), Kustha (skin diseases), Kandu (itching), Prameha (urinary disorders) etc. after proper

\footnotetext{
*Corresponding Author:

Rabinarayan Acharya

Associate Professor,

Dept of Drvayaguna

IPGT \& RA, Jamnagar, India

361008.

E-mail: drrnacharya @gmail.com
}

samaskar known as shodhana (processing or purificatory procedure) $(2,3,4)$. The seeds of Gunja are often used criminally for killing cattle where the seeds are powdered and made into a paste, with which the darts or arrows are dressed (5) The concept of Shodhana (processing or purification) in Ayurveda is not only a process of purification or detoxification but also a process to enhance the potency and efficacy of the drug (6).

The Gunja seed contains number of chemical constituents like alkaloid, steroid, flavones, triterpenoides, proteins, amino acids etc., among which an albumotoxin, abrin (a highly toxic protein) is considered the main responsible constituent for the poisonous effect of Abrus precatorius Linn. With an estimated human fatal dose of $0.1-1 \mu \mathrm{g} / \mathrm{k}(7,8)$, and it 
is reported that boiling renders the seed harmless (5).

Effect of shodhana on Gunja seeds with cow,s milk and kanji reveals that the process of shodhana resulted in depletion of more toxic alkaloid hypaphorine and protein abrin(9) and it is also reported that Gunja seeds after shodhana with Godugdha shows more significant antimicrobial activity than the raw Gunja seeds (10). But reporting of effect on different other parameters is lacking. Hence, the present study carried out to evaluate the impact of shodhana of Gunja seeds, through Godugdha on physicochemical and HPTLC profile study.

\section{Material and methods: \\ Collection and selection of drug:}

The plant Gunja (Abrus precatorius L., Fabaceae), was identified by expert plant taxonomist with help of different flora and its mature seed (red variety) were personally collected from Gunja plants from surrounding place of Jamnagar, Gujarat in their natural habitat, during the month of November - January. The fully matured dry seeds were first dropped in a beaker containing water. The seeds those floated on the surface of water or found broken, fade in colour were rejected. The seeds, those settled at the bottom of the beaker were selected for purification after being dried in air and were made in to coarse powder with help of a mechanical grinder and were kept in a glass jar, considered as Raw Gunja Seeds (RGS), to be used for all shodhana purpose.

\section{Equipment for Shodhana (Purification):}

Stainless steel vessel $(20 \mathrm{~cm}$ x 30 $\mathrm{cm})$; capacity of $7 \mathrm{~L}$, used as Dolayantra, Stainless steel $\operatorname{rod}(28 \mathrm{~cm})$, Stainless steel vessel $(48 \mathrm{~cm} \mathrm{x} 30 \mathrm{~cm} \mathrm{x7} \mathrm{cm} \mathrm{);} \mathrm{capacity}$ of $3 \mathrm{~L}$., Cotton threads $30 \mathrm{~cm}$ in length, Measuring mug (capacity of 1L), Muslin cloth (45 cm x $45 \mathrm{~cm}$ ), Digital weighing machine, Digital induction cooker, stainless steel spatula (length: $30 \mathrm{~cm}$ ), and measuring cylinder $(10 \mathrm{ml}, 25 \mathrm{ml})$.

\section{Procedure:}

In this study, Shodhana of Gunja seeds (Coarse powder) were carried out by one of the classically approved methods (1). Each Shodhana procedure was repeated for three times to establish the validation of the pharmaceutical processing. Shodhana of Gunja was performed by the process of Swedana (boiling) in Godugdha (12). $100 \mathrm{~g}$ of Raw Gunja seeds (RGS) were kept in a muslin cloth and made into a pottali. The pottali was hanged in a steel vessel and freshly collected Godugdha was filled in the vessel, up to the complete immersion of the pottali as per standard Swedana procedure (11). Boiled on an induction cooker, for six hours at $100^{\circ} \mathrm{C}$, throughout the experiments. Total 7 litres of Godugdha was utilized for one batch throughout the process. After boiling for six hours, the seeds were taken out from pottali and washed with lukewarm water followed by removal of seed coat and kept on a glass plate, for the shade drying. After proper drying, the seeds were collected and stored in air tight glass container and being labeled as 'Godugdha shodhita Gunja seed' (GSGS).

Same procedure was followed for the Shodhana of Gunja seed with Water (obtained from RO plant) and the final product was labeled as Water shodhita Gunja seed (WSGS).

\section{Preparation of sample:}

The Raw (RGS) and shodhita Gunja (Both GSGS \& WSGS) seeds were powdered with mechanical grinder and passed though mesh no. 60 .

\section{Physico chemical parameters:}

Assessment of the parameters such as foreign matter, moisture content, ash value, acid insoluble ash, $\mathrm{pH}$ with $\mathrm{pH}$ paper, water soluble extractive value, 
alcohol soluble extractive value, foaming index and swelling index were carried out following standard procedures recommended by Ayurvedic Pharmacopoeia of India(API) $(13,14)$.

\section{HPTLC study: (15)}

\section{Chemicals}

Percolated silica gel $60 \mathrm{~F}_{254}$ TLC aluminum plates $(10 \times 10 \mathrm{cms}, 0.2 \mathrm{~mm}$ thick), AR grade toluene, ethyl acetate, glacial acetic acid, methanol was obtained from M/S Merck Ltd. Mumbai, India.

\section{Samples for HPTLC}

The extract of all three samples (RGS, GSGS \& WSGS) for HPTLC, were made in same process as mentioned below.

1. Methanolic extract - $2 \mathrm{~g}$ of sample was macerated with $20 \mathrm{ml}$ of methanol for 24 hrs \& filtered. Filtrate was concentrated to $5 \mathrm{ml} \&$ used for spotting.

The samples were titled as Track-1, Track-2 \& Track-3.

Track-1: $\quad$ Methanolic extract of Raw Gunja seed.

Track-2: Methanolic extract of Godugdha shodhita Gunja seed.

Track-3: $\quad$ Methanolic extract of Water shodhita Gunja seed.

Mobile phase: Toluene: Ethyl acetate: Glacial acetic acid (6.5: 3.5: 0.2) v/v/v

Detection: Spray with Vanilline- $\mathrm{H}_{2} \mathrm{SO}_{4}$.

\section{Chromatographic conditions}

\begin{tabular}{|l|l|}
\hline Application mode & Camag Linomat V \\
\hline $\begin{array}{l}\text { Development } \\
\text { Chamber }\end{array}$ & $\begin{array}{l}\text { Camag Twin } \\
\text { through Chamber. }\end{array}$ \\
\hline Plates & $\begin{array}{l}\text { Precoated Silica } \\
\text { Gel GF254 Plates. }\end{array}$ \\
\hline Chamber Saturation & $30 \mathrm{~min}$. \\
\hline Development Time & $30 \mathrm{~min}$. \\
\hline $\begin{array}{l}\text { Development } \\
\text { distance }\end{array}$ & $7 \mathrm{~cm}$. \\
\hline Scanner & Camag Scanner III. \\
\hline Detection & $\begin{array}{l}\text { Deuterium lamp, } \\
\text { Tungsten lamp }\end{array}$ \\
\hline Data System & Win cats software \\
\hline
\end{tabular}

The developed plate was scanned to obtain densitogram in visible range from $600 \mathrm{~nm}$ to $800 \mathrm{~nm}$ with $100 \mathrm{~nm}$ interval.

\section{Results and Discussion}

During Shodhana of Gunja with Godugdha and water, change in the color of both the media, from its normal colour to reddish ting, was noticed and it might be due to the removal of color containing materials from the endosperm of the seeds. The reddish cream colour powder of raw seeds turned into brownish color in case of Godugdha shodhita Gunja seed and Ash colour in case of water shodhita Gunja seed after shodhana (Table-1). After shodhan with Godugdha and water, $85.96 \%$ and $91.66 \%$ of purified Gunja seed were obtained respectively.[Table-2] It might be due to the extraction of more soluble mass from the seeds by Godugdha than water.

It was observed that the moisture content of Godugdha shodhita Gunja seed was comparatively lower than the raw and water shodhita Gunja seed [Table-3]. Determination of moisture content of drug is one of the important methods in plant standardization. Excess of moisture in a sample may encourage growth of microbes. Lower value of moisture content indicates less chances of microbial growth (11). Ash value was decreased in case of all samples after purification. Ash mainly contains inorganic radicles and it should be totally free from carbon particles. Lower the carbon particle in ash reduces the ash value which indicates more purity of a drug. The water soluble extractive value in Godugdha shodhita Gunja seed was found higher than raw water shodhita Gunja seed. It is being observed that all samples are acidic [Table-3]. Lower the $\mathrm{P}^{\mathrm{H}}$ value indicates more acidic in nature, which is more capable to inhibit microbes.

In HPTLC, at short UV 254nm, different spots were found in all three samples indicating presence of different 
components. [Table-4] Presence of one common $\mathrm{Rf}$ value (0.01) in all three samples, indicates the presence of one common component to all three samples.

At long UV $366 \mathrm{~nm}$, raw Gunja seed, Godugdha shodhita Gunja seed and water shodhita Gunja seed showed 6, 5 and 5 spots respectively. [Table-5] From the below mentioned spectral comparison (Fig-9, Fig-10, Fig-11) some same Rf value were found in case of all three samples i.e. $0.32,0.48 \& 0.96$. From which it can be narrated that the presence of same component is possible in case of all three samples.

\section{Conclusion:}

From this study, it is concluded that shodhana alters the physicochemical parameters of Gunja seeds and also the Rf value of the sample in HPTLC. Numbers of spots were decreased under both $254 \mathrm{~nm}$ and 366nm after shodhana, indicating denaturation of some component after shodhana.

\section{Reference:}

1. Pranacharja Shri Sadananda Sharma, Pandit Kasinathshastrina. Rasatarangini. Delhi; Motilal Banarasidas; 2009. 727-733p.

2. Gogte VM. Ayurvedic Pharmacology $\&$ Therapeutic Uses of Medicinal Plants. 1st edition. Mumbai; Bharatiya Vidya Bhavan; 2000, 345-347p.

3. Review on Indian plants. Indian council of medical research. New Delhi; 2004. 24p.

4. Malati G Chauhan and A P G Pillai. Microscopic profile of Drugs used in Indian Systems of Medicine. Vol-3. Seed drugs, Part-1. 2011. 1p.
5. Kritikar K.R \& Basu B.D. Indian medicinal plants. Vol-1. DehraDun; International book distributors; 766p.

6. Shastri JLN. Dravyaguna Vijnana. $1^{\text {st }}$ edition. Vol.I. Varanasi; Choukhamba Orientalia; 2009. 320p.

7. Parikh C.K. Parikh's Test book of Medical Jurisprudence Forensic Medicine and Toxicology. Sixth edition. Darya Ganj, New Delhi110002(India); CBS Publishers \& Distributors. 4596/1A, 11. 2007. 9.31$11.16 \mathrm{p}$.

8. The wealth of India. Raw materials. Vol-I: A. New Delhi; Revised version.council of scientific \& Industrial research; 2003. 18-20p.

9. Debnath Singh Gautam, R. Banerji, S.Malhotra. Effect of shodhana on the toxicity of Abrus Precatorius. Ancient science of life. October 1998; vol.No 18 (2).

10. Comparative study: Antimicrobial activity of Ashodhita and Shodhita Shwet Gunja beej (Abrus precatorius Linn.). Nashik; Maharashtra University of Health Sciences, 2006-2007.

11. Lohar D.R. Protocol for testing, Ayurvedic, Siddha, Unani medicines.Ghaziaba; Government of India, Depertment of Ayush, Ministry of Health \& Family Welfare, Pharmacopoeial laboratory for Indian medicines, 30 ${ }^{\text {th }}$ March 2007.

12. Ayurvedic Pharmacopoeia of India (API). First edition. Part-II, Vol-II, Appendices-2. New Delhi; Government of India, Ministry of Health and Family Welfare, Department of AYUSH; 2008. 159161p.

13. Anonymous, Planner Chromatography, Modern Thin layer Chromatography. Switzerland; 1999. 2-16p. 
Table 1:_Organoleptic characters of raw, Godugdha and water shodhita Gunja seed powder

\begin{tabular}{|c|c|c|c|c|c|}
\hline SL.NO & SAMPLE & COLOUR & ODOUR & TASTE & APPEARENCE \\
\hline 1 & RGS & $\begin{array}{c}\text { Reddish } \\
\text { cream }\end{array}$ & Typical & Bitter & Smooth and shiny \\
\hline 2 & GSGS & $\begin{array}{c}\text { Brownish } \\
\text { after drying }\end{array}$ & $\begin{array}{c}\text { Characteristic } \\
\text { of milk }\end{array}$ & $\begin{array}{c}\text { Sweetish } \\
\text { bitter }\end{array}$ & Dull \\
\hline 5 & WSGS & Ash color & Typical & Bitter & Dull \\
\hline \multicolumn{7}{|c|}{ RGS= Raw gunja seed; GSGS= Godugdha shodhita Gunja seed; WSGS= Water }
\end{tabular}

shodhita Gunja seed

Table 2. Effect of Shodhana on yield of final product after shodhana with Godugdha and water.

\begin{tabular}{|c|c|c|c|}
\hline SAMPLE & $\begin{array}{c}\text { INITIAL } \\
\text { QUANTITY(g) }\end{array}$ & $\begin{array}{c}\text { FINAL } \\
\text { WEIGHT } \\
\text { (Avg.)(g) of } \\
\text { three batches }\end{array}$ & $\begin{array}{c}\text { PERCENTAGE OF } \\
\text { WEIGHT LOSS(\%) }\end{array}$ \\
\hline GSGS & 100 & 85.96 & $14.04 \%$ \\
\hline WSGS & 100 & 91.66 & $8.34 \%$ \\
\hline
\end{tabular}

GSGS= Godugdha (Cow's milk) shodhita Gunja seed; WSGS= Water shodhita Gunja seed

Table 3. Physico-chemical parameter of raw and shodhita Gunja seeds

\begin{tabular}{|c|c|c|c|}
\hline Test Parameters & Sample:1 (RGS) & $\begin{array}{c}\text { Sample:2 } \\
\text { (GSGS) }\end{array}$ & $\begin{array}{c}\text { Sample:3 } \\
\text { (WSGS) }\end{array}$ \\
\hline Description & $\begin{array}{c}\text { Outer coat red with black } \\
\text { spot }\end{array}$ & $\begin{array}{c}\text { Brownish } \\
\text { after drying }\end{array}$ & $\begin{array}{c}\text { Ash } \\
\text { colour }\end{array}$ \\
\hline Foreign matter & Nil & Nil & Nil \\
\hline Moisture content & $9.5 \% \mathrm{w} / \mathrm{w}$ & $9.025 \%$ & $9.49 \%$ \\
\hline Ash value & $4.944 \% \mathrm{w} / \mathrm{w}$ & $4.644 \%$ & $4.096 \%$ \\
\hline Acid insoluble ash & $1.5 \% \mathrm{w} /$ & $0.34 \%$ & $0.54 \%$ \\
\hline $\mathbf{P}^{\mathrm{H}}$ ( p ${ }^{\mathrm{H}}$ paper) & 5.5 & 5.5 & 5.5 \\
\hline Water soluble extractive value & $10.35 \% \mathrm{w} / \mathrm{v}$ & $11.38 \%$ & $6.087 \%$ \\
\hline Alcohol soluble extractive value & $1.5 \%$ & $0.69 \%$ & $0.39 \%$ \\
\hline Foaming index & $<100$ & $<100$ & $<100$ \\
\hline Swelling index & $3 \mathrm{ml}$ & $4.5 \mathrm{ml}$ & $3.5 \mathrm{ml}$ \\
\hline
\end{tabular}

RGS $=$ Raw gunja seed; GSGS= Godugdha shodhita Gunja seed; WSGS $=$ Water shodhita Gunja seed 
Table 4:- $\mathbf{R}_{\mathrm{f}}$ value in Short UV $254 \mathrm{~nm}$ of the methanolic extract of all three samples

\begin{tabular}{|c|c|c|c|}
\hline SL NO & SAMPLE & NO. OF SPOT & R $_{\mathbf{F}}$ VALUE \\
\hline 1 & RGS & 8 & $0.01,0.04,0.11,0.20$, \\
& & & $0.24,0.27,0.46,0.90$ \\
\hline 2 & GSGS & 6 & $0.01,0.28,0.39$, \\
& & & $0.46,0.60,0.69$ \\
\hline 3 & WSGS & 4 & $0.01,0.26,0.88,0.91$ \\
\hline
\end{tabular}

RGS= Raw gunja seed; GSGS= Godugdha shodhita Gunja seed; WSGS= Water shodhita Gunja seed

Table 5:- $R_{f}$ value in long UV 366nm of the methanolic extract of all three samples

\begin{tabular}{|c|c|c|c|}
\hline SL NO & SAMPLE & NO. OF SPOT & RF VALUE $_{\text {VA }}$ \\
\hline 1 & RGS & 6 & $0.01,0.05,0.08,0.25,0.41$, \\
& & & 0.91 \\
\hline 2 & GSGS & 5 & $0.00,0.18,0.38,0.46,0.92$. \\
\hline 3 & WSGS & 5 & $0.01,0.40,0.47,0.87,0.93$ \\
\hline
\end{tabular}

RGS= Raw gunja seed; GSGS= Godugdha shodhita Gunja seed; WSGS= Water shodhita Gunja seed

HPTLC profile:-

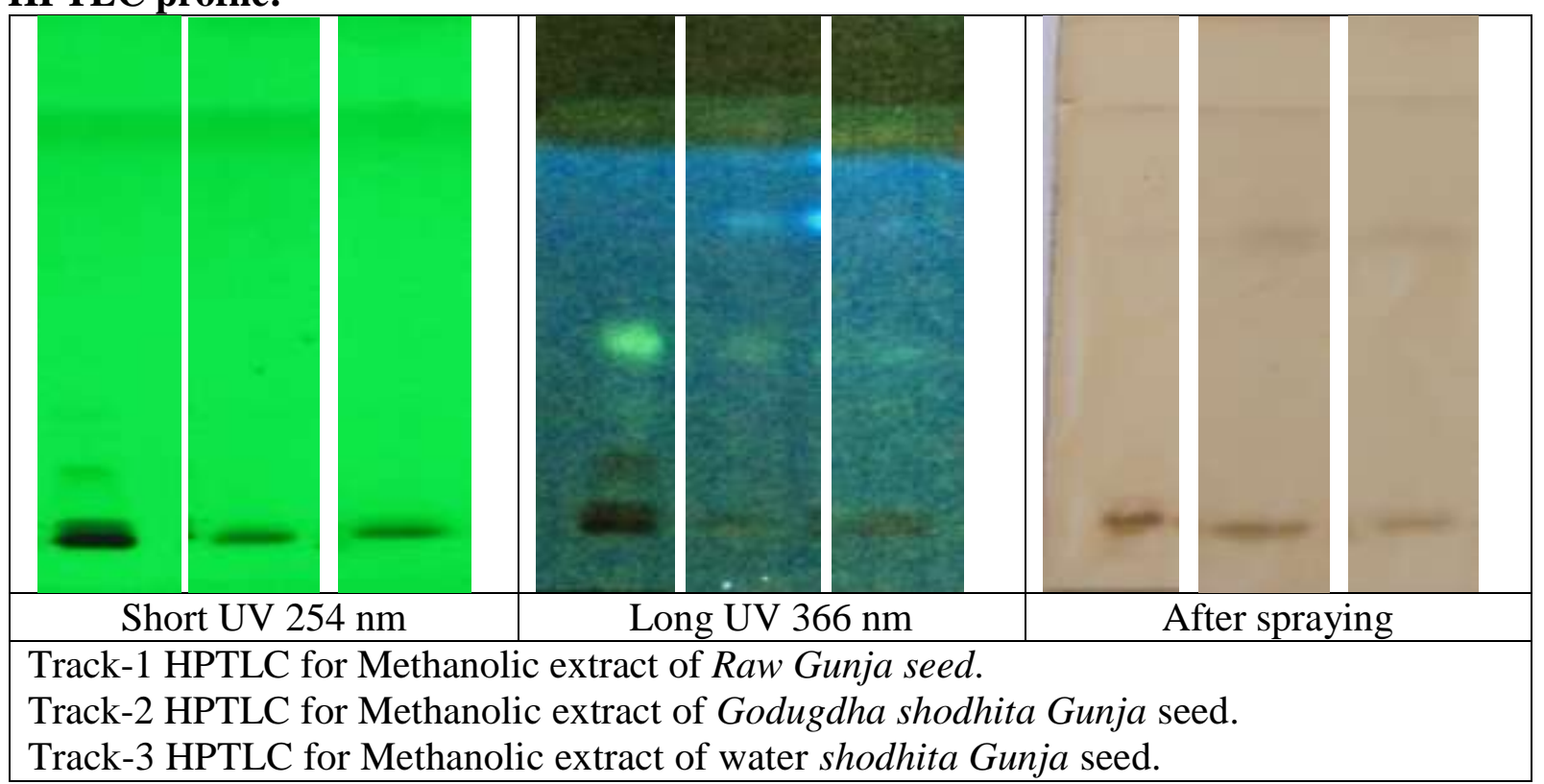




\section{Densitogram of Standard (visible Spectrum Comparison)}

Track-1 HPTLC for Methanolic extract of Raw Gunja seed.

Track-2 HPTLC for Methanolic extract of Godugdha shodhita Gunja seed.

Track-3 HPTLC for Methanolic extract of water shodhita Gunja seed

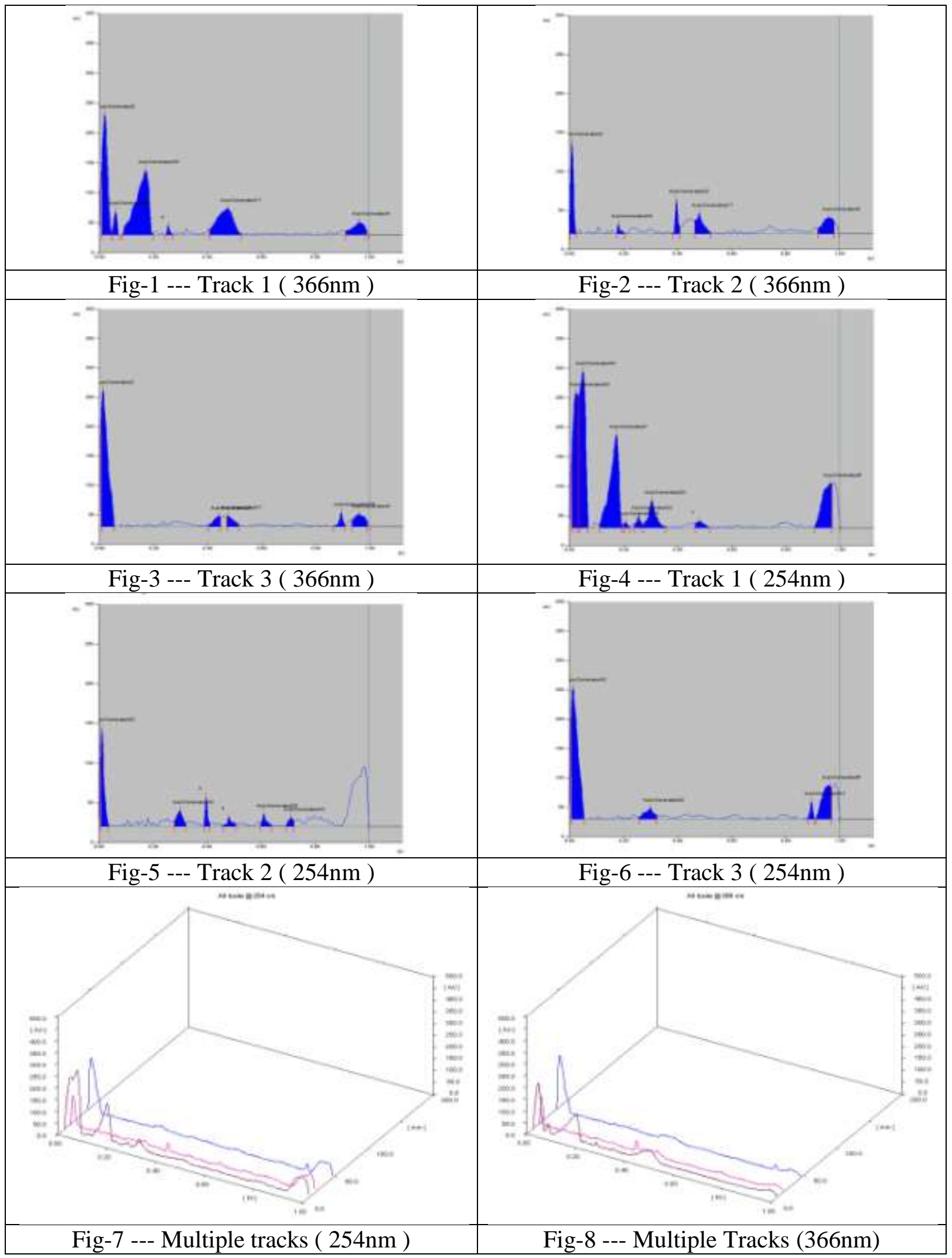




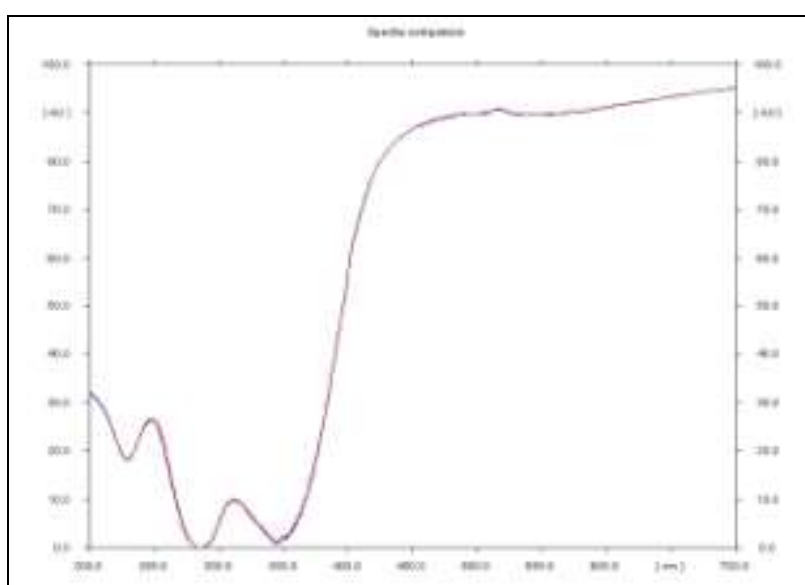

Fig-9 --- U.V.Spectral comparison Rf 0.32 $\mathrm{T}-1,2,3$

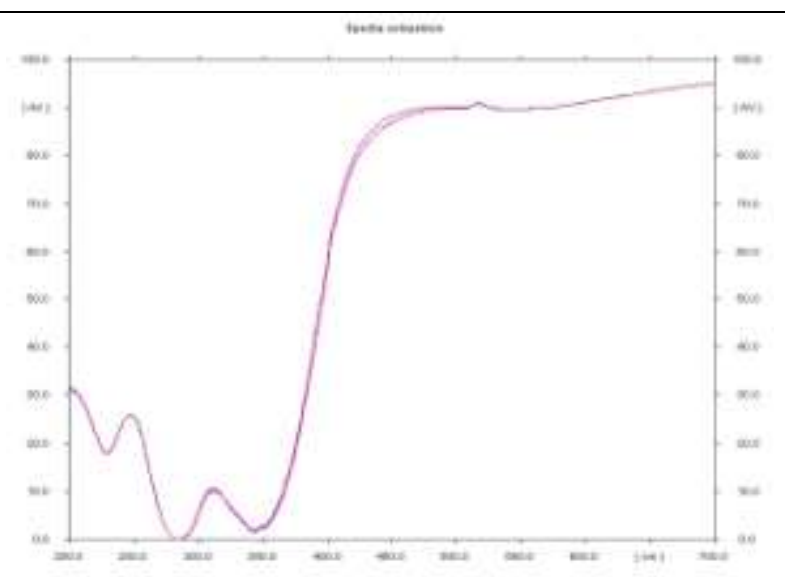

Fig-10 --- U.V.Spectral comparison Rf 0.48 $\mathrm{T}-1,2,3$

Fig-11 --- U.V.Spectral comparison Rf 0.96 T-1,2,3

$* * * * *$ 